\title{
Classical Biological Control of Air Potato in Florida ${ }^{1}$
}

\author{
T. D. Center and W. A. Overholt ${ }^{2}$
}

\section{Introduction}

Air potato (Dioscorea bulbifera) is an herbaceous, perennial twining vine that attains lengths of $20 \mathrm{~m}$ or more, enabling it to overtop and smother native vegetation (Schmitz et al. 1997, Figure 1). Although originally thought to have an African origin (Overholt et al. 2003), subsequent genetic analysis determined that Florida material likely originated in China (Croxton et al. 2011).

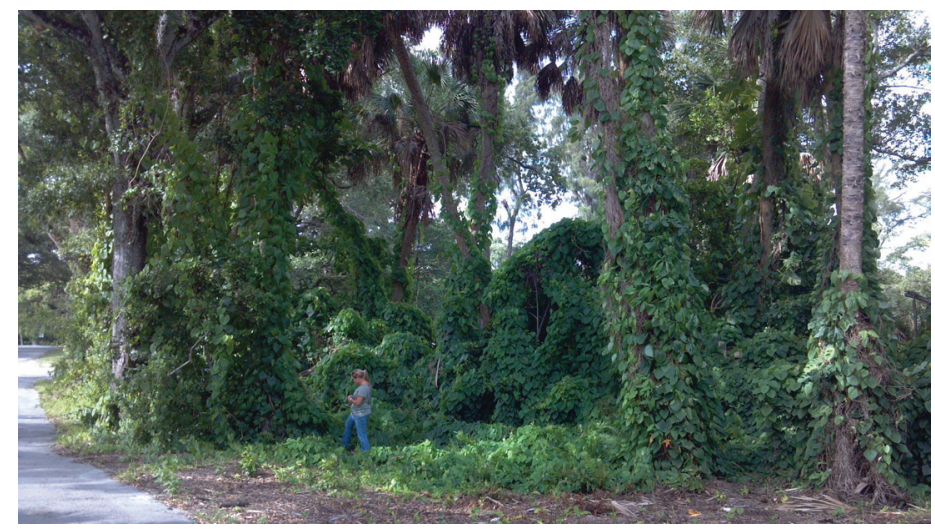

Figure 1. Air potato infestation at Snyder park in Fort Lauderdale. This is one of the release sites for Lilioceris cheni.

Air potato was introduced to Florida in 1905 when it was sent to the USDA by Henry Nehrling, who later noted its invasive potential (Morton 1976). It has since become extremely aggressive (Hammer 1998). By the 1980s, air potato vines were growing in thickets, waste areas, and hedges or fencerows in many parts of south and central Florida (Bell and Taylor 1982). By 1999, air potato was recognized as transforming plant communities by displacing native species, changing community structure and disrupting ecological functions (FLEPPC 2003).

\section{Biology of Air Potato}

Vegetative propagation occurs primarily through aerial tubers-the "potatoes" that give the plant its common name. Aerial tubers, also called bulbils, form in leaf axils during late summer. These bulbils, which may weigh up to $1 \mathrm{~kg}$ ( $2 \mathrm{lbs}$ ), drop to the ground when the vines die back during the cooler months. Vines re-sprout during autumn from subterranean tubers or from bulbils lying on the ground. Seed production is rare in Florida, where air potato spreads mainly through human dispersal of the bulbils (Schultz 1993). Besides Florida, air potato has also been reported from most of the Gulf Coast states, Puerto Rico, and Hawaii. Climate matching models suggest that air potato could also spread along the Atlantic Coast as far as Charleston, South Carolina (Overholt et al., 2008).

\section{The Air Potato Leaf Beetle, Lilioceris cheni}

Lilioceris cheni Gressit \& Kimono (Coleoptera: Chrysomelidae) is a rather large (approximately $9 \mathrm{~mm}$ or about $3 / 8$ inch long) orange-red Asian leaf beetle in the subfamily Criocerinae (Figure 2) (Tishechkin et al. 2011). The beetle is a host-specific specialist that feeds and develops only on D. bulbifera (Pemberton and Witkus 2010). The USDA-ARS Invasive Plant laboratory, located in Fort Lauderdale, acquired this beetle from China and has begun an ambitious release program aimed at controlling air potato. Permission

1. This document is ENY-864, one of a series of the Entomology and Nematology Department, Florida Cooperative Extension Service, Institute of Food and Agricultural Sciences, University of Florida. Original publication date October 2012. Visit the EDIS website at http://edis.ifas.ufl.edu.

2. T. D. Center, USDA/ARS Invasive Plant Research Laboratory, Fort Lauderdale, FL; and W. A. Overholt, UF/IFAS Indian River Research and Education Center, Fort Pierce, FL. 
to release this beetle was acquired from USDA-APHIS after extensive testing demonstrated its host specificity with virtually no risk to other plant species (Pemberton and Witkus, 2010).

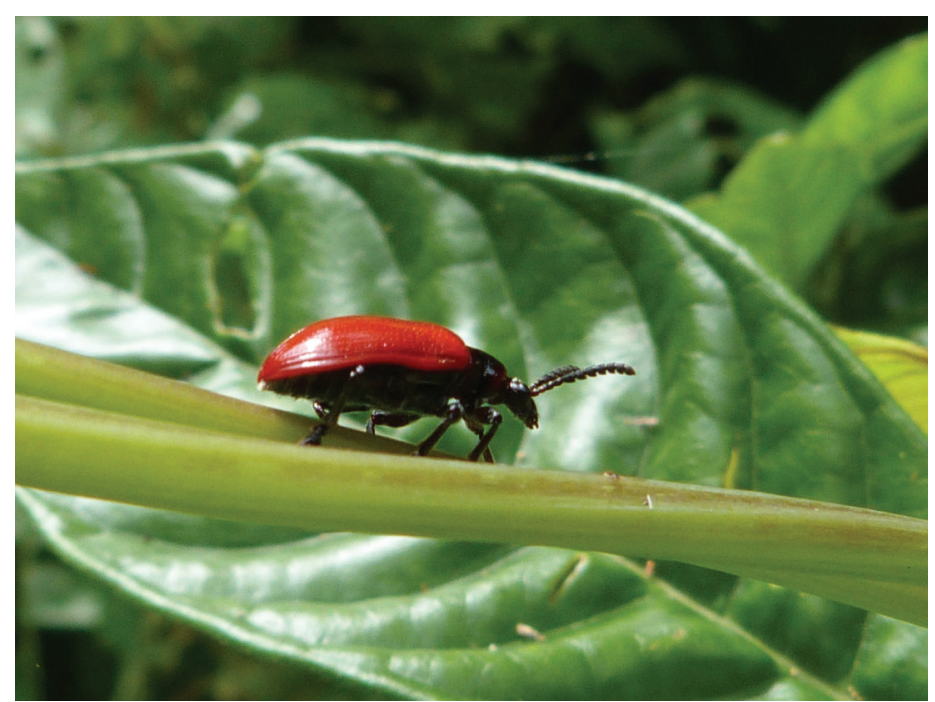

Figure 2. Adult Lilioceris cheni beetle.

\section{Biology of Lilioceris cheni}

Pale white, oblong eggs of $L$. cheni are deposited in loosely aggregated clusters on the undersides of young, expanding leaves of its host plant. The process of oviposition apparently deforms the expanding leaf, causing it to curl at the edges so that it cups around the eggs (Figure 3).

Females deposit, on average, more than 1200 eggs during their lifetime. The eggs become yellowish as the embryo develops (Figure 4). Embryonic development requires about 4 days.

Larvae are yellowish at first, becoming grayish in later instars, with black legs, head capsule, and prothoracic shield. They are often covered with a sticky secretion to which fecal material adheres. Larvae feed gregariously and skeletonize the leaves from the underside. Young, tender leaves are preferred but they also consume older, tougher leaves and are able to feed on the aerial bulbils. Complete development of the four instars requires about 8 days, with each stage lasting about 2 days.

When fully grown, larvae drop from the host plant and enter the soil. They then produce a whitish oral secretion that hardens into a foam-like cocoon. Pupation occurs gregariously, often with several pupae clumped together within a matrix of this material. Adults emerge in about 16 days, begin mating in about 10 days, and initiate

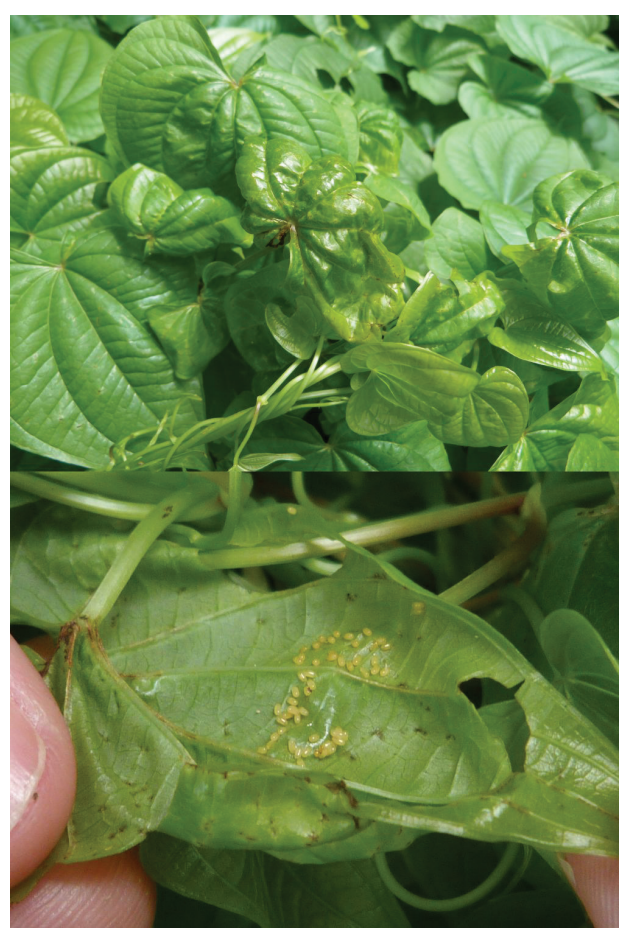

Figure 3. A deformed expanding leaf of air potato (top) and the Lilioceris cheni eggs enclosed within (bottom).

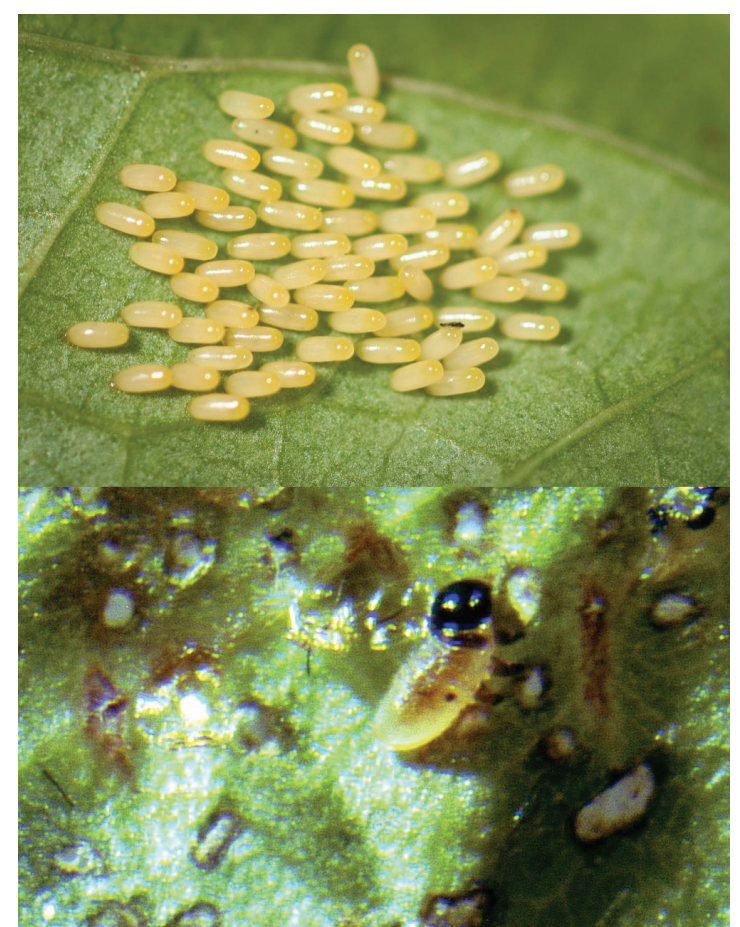

Figure 4. L. cheni eggs (top) and a freshly emerged first instar larva (bottom).

oviposition about 5 days later. The adults live for 5 months or longer.

Both adults and larvae feed on the foliage, skeletonizing the leaves (Figures 5, 6). Larvae can often be found in aggregations on the growing tips. This damage inhibits vine elongation and may reduce the ability of the plant to climb vertical structures. 


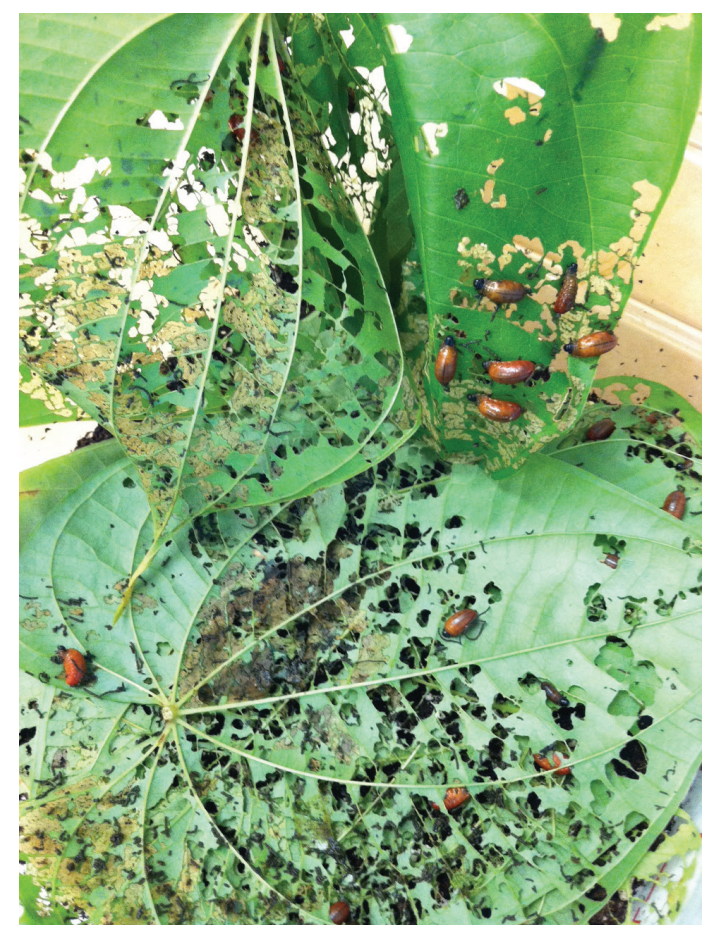

Figure 5. An aggregation of late instar L. cheni larvae feeding on air potato leaves.

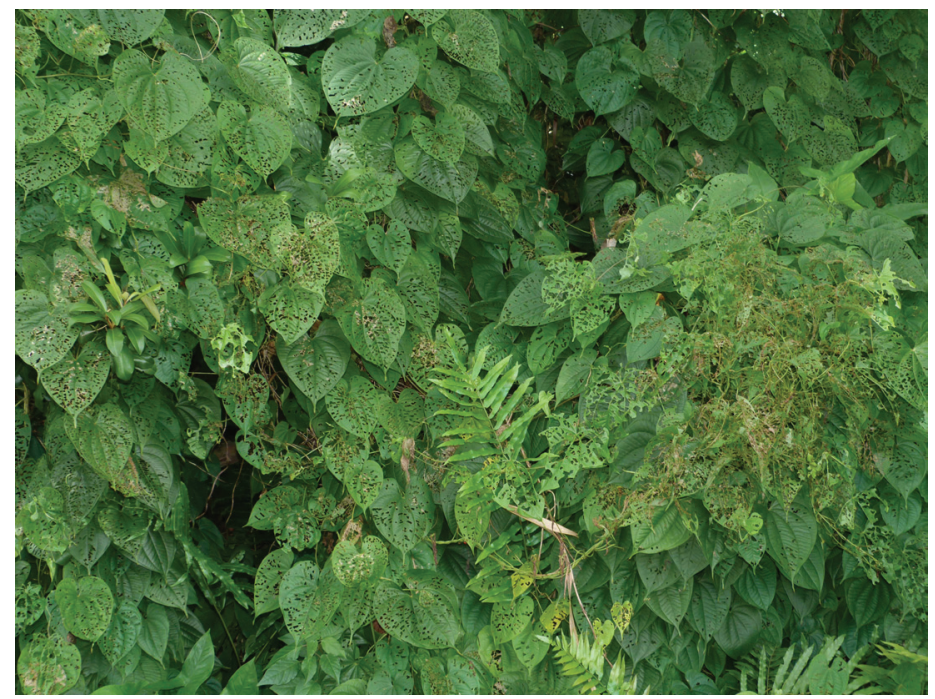

Figure 6. Air potato leaves defoliated by L. cheni at Snyder Park less than a month after release.

The host plant drops its leaves during the winter, which forces the adult beetles to go several months without food, presumably in diapause beneath leaf litter or other debris on the ground. The overwintered adults emerge during spring. Females initially lay about 90 eggs/day during a 13-day period of ovipositional activity.

\section{References}

Bell, C.R., and B.J. Taylor. 1982. Florida Wild Flowers and Roadside Plants. Laurel Hill Press, Chapel Hill, N.C.
Croxton, M.D., M.A. Andreu, D.A. Williams, W.A. Overholt, and J.A. Smith. 2011. Geographic origins and genetic diversity of air-potato (Dioscorea bulbifera) in Florida. Invasive Plant Science and Management 4: 22-30.

FLEPPC Plant List Committee. 2003. Florida Exotic Pest Plant Council's 2003 list of invasive species. Wildland Weeds 6: suppl.

Hammer, R.L. 1998. Diognosis: Dioscorea. Wildland Weeds $2: 8-10$.

Langeland, K.A., and K. CraddockBurks. 1998. Identification and Biology of Non-native Plants in Florida's Native Areas. University of Florida, Gainesville.

Morton, J.F. 1976. Pestiferous spread of many ornamental and fruit species in south Florida. Proceedings Florida State Horticultural Society 89:348-353.

Overholt, B., C. Hughes, C. Wallace, and E. Morgan. 2003. Origin of air potato identified. Wildland Weeds 7:9.

Overholt, W. A., L. Markle, M.Meisenburg, L. Raz, G. Wheeler, R. Pemberton, J. Taylor, M. King, D. Schmitz, and G.R. Parks.2008. Air Potato Management Plan.Florida Exotic Pest Plant Council. Available at: http://www.fleppc. org/Manage_Plans/AirpotatoManagementPlan_Final.pdf.

Pemberton, R.W., and G.L. Witkus. 2010. Laboratory host range testing of Lilioceris sp. near impressa (Coleoptera: Chrysomelidae) - a potential biological control agent of air potato, Dioscorea bulbifera (Dioscoreaceae). Biocontrol Science and Technology 20: 567-587.

Schmitz, D.C., D. Simberloff, R.L. Hofstetter, W.T. Haller, and D. Sutton. 1997. The ecological impact of nonindigenous plants. Pp. 39-61 in D. Simberloff, D.C. Schmitz, and T.C. Brown, eds., Strangers in Paradise: Impact and Management of Nonindigenous Species in Florida. Island Press, Washington, D.C.

Schultz, G.E. 1993. Element Stewardship abstract for Dioscorea bulbifera Air potato.The Nature Conservancy, Davis, Calif.

Tishechkin, A.K., A.S. Konstantinov, S. Bista, R.W. Pemberton, and T.D. Center. 2011. Review of the continental Oriental species of Lilioceris Reitter (Coleoptera, Chrysomelidae, Criocerinae) closely related to Lilioceris impressa (F.). ZooKeys 103: 63-83. 